\title{
Fertile Eunuch Syndrome with the Mutations (Trp8Arg and Ile15Thr) in the $\beta$ Subunit of Luteinizing Hormone
}

\author{
KOJI SHIRAISHI AND KATSUSUKE NAITO \\ Department of Urology, Yamaguchi University School of Medicine, Ube, Yamaguchi 755-8505, Japan
}

\begin{abstract}
Fertile eunuch syndrome is caused by isolated LH deficiency, but its pathophysiology still remains controversial. We report a case of fertile eunuch syndrome with homozygous Trp8Arg and Ile15Thr mutations in the LH $\beta$ subunit gene. An 18-year-old man was admitted to our hospital for hypogonadism. Examination of genitalia revealed Tanner G1PH1, whereas both testes were elastically palpated and developed up to $18 \mathrm{ml}$. Endocrinological evaluations revealed normogonadotropic hypogonadism and there were normal responses after GnRH and hCG stimulation. Intratesticular testosterone concentration was almost normal $\left(1.34 \times 10^{3} \mathrm{ng} / \mathrm{g}\right)$. By PCR direct sequencing, homozygous Trp (8) Arg and Ile (15) Thr mutations in exon 2 of LH $\beta$ were detected. Normal virilization and improved semen parameters were achieved after hCG supplementation. To our knowledge, this is the first case of fertile eunuch syndrome with homozygous Trp (8) Arg and Ile (15) Thr mutations in $\beta$ subunit of LH gene.
\end{abstract}

Key words: fertile eunuch syndrome, $\mathrm{LH} \beta$, mutation

(Endocrine Journal 50: 733-737, 2003)

MEN with fertile eunuch syndrome have eunuchoid proportions, but characteristically have developed testes with sperm, often oligoasthenozospermia, in their ejaculate. Although it is considered to be an isolated luteinizing hormone ( $\mathrm{LH}$ ) deficiency caused by disturbed gonadotropin-releasing hormone ( $\mathrm{GnRH})$ secretion in hypothalamus [1], the pathophysiology of fertile eunuch syndrome still remains controversial, and altered function of Leydig cells [2] and mutation in $\mathrm{GnRH}$ receptor in gonadtrophs [3, 4] have also been reported.

LH is a heterodimer composed of a common $\alpha$ subunit and a specific $\beta$ subunit that confers biological specificity for the receptor in Leydig cells in men [5]. The most common LH $\beta$ allele variant is the Trp8Arg and Ile15Thr mutation in exon 2, which has a carrier frequency ranging from 0 to $53 \%$ in various populations [6], including 4.7\% in Japanese men [7].

Received: June 12, 2003

Accepted: August 4, 2003

Correspondence to: Koji SHIRAISHI, M.D., Ph.D., Department of Urology, Saiseikai Shimonoseki General Hospital, 3-4-1 Kifune-cho, Shimonoseki, Yamaguchi 751-8502, Japan
Homozygous mutation was observed $2 \%$ of azoospermic individuals [7]. There has been a report of a homozygous mutation of $\mathrm{LH} \beta$ gene, which is an amino acid substitution Gln54Arg in exon 3, in an adolescent with delayed puberty, increased serum concentration of LH, normal FSH and low testosterone [8], whereas the associations of variant LH (Trp8Arg and Ile15Thr in exon 2) and male infertility or hypogonadism are unclear $[9,10]$.

To our knowledge, there is no information on the association of fertile eunuch syndrome and variant $\mathrm{LH}$. In this report, we describe a case of fertile eunuch syndrome with homozygous mutation of LH $\beta$ gene.

\section{Case Report}

An 18-year-old man consulted our clinic on March 9, 2001 for delayed puberty. Physical examination revealed a thin young male with weight of $60.5 \mathrm{~kg}$, height was $166 \mathrm{~cm}$ and arm span was $170 \mathrm{~cm}$. There were no abnormalities in breast, olfactory function and mental development. Examination of genitalia revealed Tanner G1PH1, whereas both testes were 


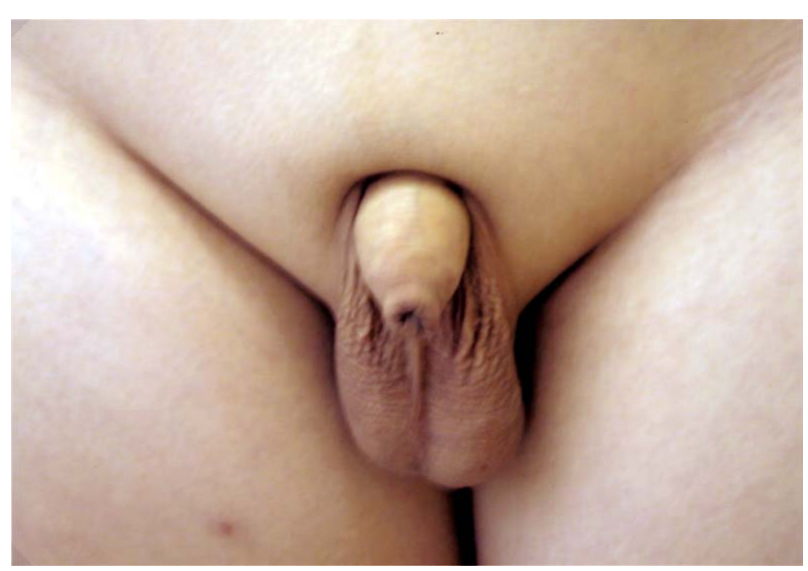

Fig. 1. Photograph of external genitalia showing prepubertal stage, while testes are comparatively well developed.

elastically palpated and developed up to $18 \mathrm{ml}$ as evaluated by punched-out orchidometer (Fig. 1). By interviewing the family members of the patient, no phenotypic abnormalities were detected. Semen analysis was oligoasthenozospermia, with a sperm count of $4.5 \times 10^{6} / \mathrm{ml}, 30 \%$ of motility, and $60 \%$ of deformity in $1.5 \mathrm{ml}$ of ejaculate. Endocrinological examination revealed normogonadtropic hypogonadism: total testosterone was $9.8 \mathrm{ng} / \mathrm{dl}(250-1100 \mathrm{ng} / \mathrm{dl}), \mathrm{LH}$ was $2.57 \mathrm{mIU} / \mathrm{l}(1.7-8.6 \mathrm{mIU} / \mathrm{l})$, and $\mathrm{FSH}$ was $3.76 \mathrm{mIU} / \mathrm{l}$ (1.6-11.0 mIU/l). Serum prolactin was $178.8 \mathrm{ng} / \mathrm{ml}$ $(57-357 \mathrm{ng} / \mathrm{ml})$. LH increased up to $52.4 \mathrm{mIU} / 1$ and FSH up to $11.9 \mathrm{mIU} / \mathrm{l} 30$ and 60 minutes after gonadotropin-releasing hormone $(\mathrm{GnRH})$ stimulation (100 $\mu \mathrm{g}$ of LH-RH intravenously), respectively. Serum testosterone increased up to $453.0 \mathrm{ng} / \mathrm{dl}$ after daily 5000 IU human chorionic gonadtropin (hCG) stimulation for 3 days. Episodic secretion of LH was recognized up to $5.72 \mathrm{mIU} / 1(4.5 \pm 0.9 \mathrm{mIU} / 1$; mean $\pm \mathrm{SD})$ during the night. The blood karyotype was $46, \mathrm{XY}$. Testicular biopsy demonstrated that more than half of the tubules showed normal degrees of spermatogenesis. There were a few small tubules with marked thickening of the basement membrane and only a few cells in the lumen. The interstitial tissue was of moderately increased density with relative rarity of mature Leydig cells (Fig. 2).

Intramuscular injection of hCG (5000 IU) twice a week (Tuesday and Friday) was started at March 23, 2001. Six months after the treatment, he achieved good virilization up to Tanner G3PH4, and increased testicular volume (both $22 \mathrm{ml}$ ). Serum testosterone concentration was elevated up to $385 \mathrm{ng} / \mathrm{dl}$. Ejaculate

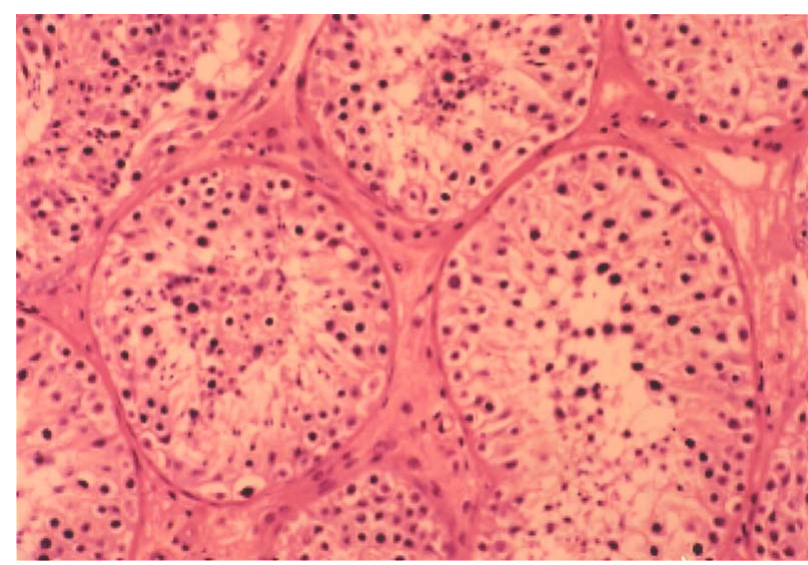

Fig. 2. Photomicrograph of testicular biopsy specimen $(\times 400)$. Many tubules showed normal degrees of spermatogenesis. The interstitial tissue was moderately increased with relative rarity of mature Leydig cells.

volume increased up to $2.8 \mathrm{ml}$ and semen parameters became normal, with sperm concentration of 25.5 $\times 106 / \mathrm{ml}, 60 \%$ of motility, and deformity was $30 \%$. In September 2002, six months after discontinuation of hCG supplementation, serum testosterone fell to $38.2 \mathrm{ng} / \mathrm{dl}$. He was followed up without any treatment because virilization was achieved and maintained.

\section{DNA amplification and sequencing analysis of LH $\beta$ gene}

Informed consent was obtained from the patient and his family and all examinations followed a protocol approved by the Ethics Committee in Yamaguchi University. Blood samples were collected from the patient. Genomic DNA was isolated from peripheral blood lymphocytes by isolation reagents (DNA extraction kit, Takara Bio. Inc.) and was used as a polymerase chain reaction (PCR) template. The primers used in this study spanned exon 2 , intron 2 and exon 3 of the LH $\beta$ gene. The 5' primer was 5'-GGGAATTC TCTTTGTGGGTGGTGTACCACGC-3' and 3' primer was 5'-GGAGGATCCGGGTGTCAGGGCTCCA-3'. The PCR amplification was performed in a total volume of $25 \mu \mathrm{L}$ reaction mixture containing $1.5 \mathrm{mM}$ of $\mathrm{MgCl}_{2}, 0.2 \mathrm{ml}$ of each dNTP, $10 \%$ dimethylsulfoxide, $100 \mathrm{ng}$ of genomic DNA, 10 pmol of each primer, and $1 \mathrm{U}$ of Taq DNA polymerase. The cycling profile consisted of denaturation at $94^{\circ} \mathrm{C}$ for 1 minute, annealing at $65^{\circ} \mathrm{C}$ for 40 seconds, and extension at $72^{\circ} \mathrm{C}$ for 1 minute. The amplified DNA was sequenced with a fluorescence-based automated se- 
$\operatorname{Arg}^{8}$

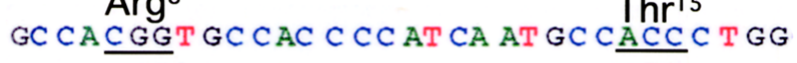
130 140

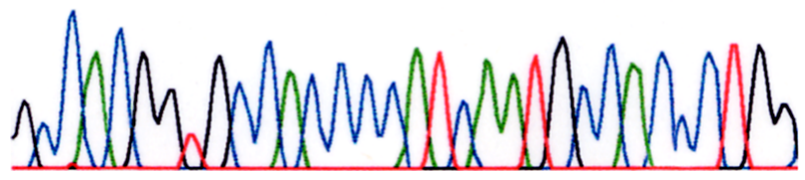

Fig. 3. DNA sequencing showing the patient's nucleotide mutations and substitutions of amino acid.

quencer (ABI PRISM version 3.2 Genetic analyzer, Perkin Elmer, Foster City, CA).

DNA sequence of $\beta$ subunit of LH gene revealed two heterozygous point mutations: a $\mathrm{T}$ to $\mathrm{C}$ transition at $\operatorname{Trp}^{8}$ (TGG) resulting in an amino acid substitution to $\mathrm{Arg}^{8}$ (CGG) and a $\mathrm{T}$ to $\mathrm{C}$ at $\mathrm{Ile}^{15}$ (ATC) resulting in an amino acid substitution to $\mathrm{Thr}^{15}$ (ACC) (Fig. 3).

Measurement of intratesticular testosterone concentration

A bit of testicular biopsy specimen was homogenated in $0.1 \mathrm{M}$ phosphate buffer and centrifuged at $2000 \mathrm{rpm}$ for $10 \mathrm{~min}$. Supernatant was transferred to tubes and stored at $-80^{\circ} \mathrm{C}$ until the assay. Testosterone concentration of the supernatant was measured by RIA (Total testosterone kit, Nippon DPC Corp.) [11]. Intratesticular testosterone concentration was $1.34 \times$ $10^{3} \mathrm{ng} / \mathrm{g}$.

\section{Discussion}

This is the first report of homozygous mutation of LH $\beta(\operatorname{Trp} 8$ Arg and Ile15Thr) in a patient presenting fertile eunuch syndrome. Conventional endocrinological evaluations, including episodic secretion of $\mathrm{LH}$ during the night time and responses for $\mathrm{Gn}-\mathrm{RH}$ and hCG, revealed that there were no disorders in the hypothalamus-pituitary-Leydig cell axis. Achievement of favorable virilization after hCG supplementation suggests normal response in androgen-dependent organs. In men, variant LH has been reported to affect the course of puberty [9]; on the other hand, it was not associated with male infertility [10]. These observations suggest that homozygous mutation of LH $\beta$ (Trp8Arg and Ile15Thr) may be a possible cause of fertile eunuch syndrome.

Many patients of this disease show normal or low normal LH secretion, but not isolated LH deficiency [12-14], therefore another cause has to be considered. Variant LH $\beta$ is undetectable in a radioreceptor assay compared with the wild-type hormone [8] and it has lower receptor-binding activity [15]. Inactivating human LH $\beta$ mutation results in absence or decreased number of Leydig cells [6] because LH is necessary for normal development of Leydig cells. Additionally, there are several differences in intracellular trafficking by variant LH stimulation in Leydig cells [16]. Testicular biopsy finding (decreased number of mature Leydig cells) suggests the deterioration of ligand stimulation, following insufficient testosterone production. However, the prevalence of these LH $\beta$ polymorphisms was reported to be up to $53 \%$ [6], since not all men with variant LH $\beta$ present hypogonadism. Contrary to our case, a boy with homozygous mutation detected by immunological assays had normal pubertal onset [7]. It is unclear whether these genetic alterations represent causative mutations or simply polymorphisms [17, 18]. In different from Gln54Arg mutation in exon 3 [8], hypogonadism cannot be explained clearly only by Trp8Arg and Ile15Thr mutations in exon 2. Possible alterations in $\mathrm{LH}$ action (e.g., binding affinity to $\mathrm{LH}$ receptor, alterations in intracellular signal transduction) should also be clarified.

The initiation of spermatogenesis normally occurs under the influence of LH and FSH. Even a little testosterone can initiate spermatogenesis under sufficient FSH concentration, because spermatogenesis can be induced hypogonadtropic hypogonadism patients with human menopausal gonadotropins (hMG) [19]. One study showed that intratesticular testosterone concentration was $1.54 \pm 1.18 \times 10^{3} \mathrm{ng} / \mathrm{g}($ mean $\pm \mathrm{SD})$ in adult and infertile men without any pubertal delay [11]. In our case, there was adequate LH to stimulate intratesticular testosterone $\left(1.34 \times 10^{3} \mathrm{ng} / \mathrm{g}\right)$ with resultant spermatogenesis but insufficient testosterone to promote virilization [1].

Usually, low concentrations of serum testosterone provoke hypergonadtropic hypogonadism through negative feedback. Why did our case not represent hypergonadtropic hypogonadism? The variant LH was found to have a shorter half-life than that of the wild-type LH [20]. If production of the variant LH in gonadotroph is accelerated, the serum LH may appear normal or low. Additionally, Gn-RH secretion is also regulated by inhibin, which is produced from Sertoli cells under the regulation of FSH [21]. Raivio et al. 
suggested that the variant LH was involved in the regulation of the GH-insulin-like growth factor I axis [9].

However, the spermiogram of fertile eunuch patients is oligoasthenozoospermia in many cases, we must be aware that it can be improved by proper hormonal supplementation. Hormonal therapy may provide a simpler and more inexpensive means of achieving sexual maturation and fertility. In an era of artificial reproductive technology (ART), men with sperm in their testes become "fertile", even if their spermiograms are azoospermia. The term "fertile eunuch syndrome" remains somewhat of a misnomer that continues to invite misunderstanding. Evaluation of variant LH may help our understanding of unexplained hypogonadism and infertility.

\section{Acknowledgement}

We thank Dr. Toshihiko Aki (Department of Legal Medicine, Yamaguchi University) for technical advice on DNA sequencing.

\section{References}

1. Grumbach MM, Styne DM (1998) Puberty: Ontogeny, Neuroendocrinology, Physiology, and Disorders. In: Wilson JD, Foster DW, Kronenberg HM, Larsen PR (eds) Williams Textbook of Endocrinology, 9th ed. WB Saunders, Philadelphia: 1509-625.

2. Makler A, Glezerman M, Lunenfeld B (1977) The fertile eunuch syndrome: An isolated Leydig-cell failure? Andrologia 9: 163-170.

3. de Roux N, Young J, Misrahi M, Genet R, Chanson P, Schaison G, Milgrom E (1997) A family with hypogonadotropic hypogonadism and mutations in the gonadotropin-releasing hormone receptor. $N$ Engl $J$ Med 337: 1597-1602.

4. Pitteloud N, Boepple PA, DeCruz S, Valkenburgh SB, Crowley WF Jr, Hayes FJ (2001) The fertile eunuch variant of idiopathic hypogonadotropic hypogonadism: spontaneous reversal associated with a homozygous mutation in the gonadotropin-releasing hormone receptor. J Clin Endocrinol Metab 86: 2470-2475.

5. Gharib SD, Wierman ME, Shupnik MA, Chin WW (1990) Molecular biology of pituitary gonadotropins. Endocr Rev 11: 177-199.

6. Huhtaniemi I, Jiang M, Nilsson C, Pettersson K (1999) Mutations and polymorphisms in gonadotropin genes. Mol Cell Endocrinol 151: 89-94.

7. Toyoshima $\mathrm{T}$ (2001) Frequency of luteinizing hormone-beta gene variants is increased in Japanese patients with idiopathic azoospermia. Jpn J Fertil Steril 46: 111-115.

8. Weiss J, Axelrod L, Whitcomb RW, Harris PE, Crowley WF, Jameson JL (1992) Hypogonadism caused by a single amino acid substitution in the $\beta$ subunit of luteinizing hormone. $N$ Engl J Med 326: 179183.

9. Raivio T, Huhtaniemi I, Anttila R, Siimes MA, Hagenäs L, Nilsson C, Pettersson K, Dunkel L (1996) The role of LH $\beta$ gene polymorphism in the onset and progression of puberty in healthy boys. J Clin Endocrinol Metab 81: 3278-3282.

10. Ramanujam LN, Liao W-X, Roy AC, Ng SC (2000) Association of molecular variants of luteinizing hormone with male infertility. Hum Reprod 15: 925-928.

11. Ichikawa $\mathrm{T}$ (1995) A study on intratesticular aromatase activity in male infertility. Jpn J Urol 86: 940-948.

12. Christiansen P (1972) Urinary gonadotropins in nine fertile eunuchs. Acta Endocrinol 71: 454-468.

13. Williams C, Wieland RG, Zorn EM, Hallberg MC (1975) Effect of synthetic gonadotropin-releasing hormone $(\mathrm{GnRH})$ in a patient with the "fertile eunuch" syndrome. J Clin Endocrinol Metab 41: 176-179.

14. Smals AGH, Kloppenborg PWC, van Haelst UJG, Lequin R, Benraad TJ (1978) Fertile eunuch syndrome versus classic hypogonadotropic hypogonadism. Acta Endocrinol 87: 389-399.

15. Liao WX, Goh HH, Roy AC (2002) Functional characterization of a natural variant of luteinizing hormone. Hum Genet 111: 219-224.

16. Manna PR, Joshi L, Reinhold VN, Aubert ML, Suganuma N, Pettersson K, Huhtaniemi IT (2002) Synthesis, purification and structural and functional characterization of recombinant form of a common genetic variant of human luteinizing hormone. Hum Mol Genet 11: 301-305.

17. Roy AC, Liao W-X, Arukumaran S, Ratnam SS (1996) Identification of seven novel mutations of the LH $\beta$ gene by SSCP. Mol Cell Biochem 16: 151-153.

18. Liao W-X, Roy AC, Chan C, Arukumaran S, Ratnam SS (1998) A new molecular variant of luteinizing hormone associated with female infertility. Fertil Steril 69: 102-106.

19. Jones TH, Darne JF (1993) Self-administered subcutaneous human menopausal gonadotropin for the stimulation of testicular growth and the initiation of spermatogenesis in hypogonadtropic hypogonadism. 
Clin Endocrinol 38: 203-208.

20. Haavisto AM, Pettersson K, Bergendahl M, Virkamaki A, Huhtaniemi IT (1995) Occurrence and biological properties of a common genetic variant of luteinizing hormone. J Clin Endocrinol Metab 80: 1257-1263.
21. Swerdloff RS, Wang C (1998) Physiology of hypothalamic-pituitary function. In: Walsh PC, Retik AB, Vaughan ED Jr, Wein AJ (eds) Campbell's Urology. 7th ed. WB Saunders, Philadelphia: 1239-1253. 